History of Medicine. Yale University seeks a tenure-track Assistant or junior Associate Professor in the history of medicine beginning July 1, 2014. Field, region, and period are open, but the committee will especially welcome applications from scholars whose work reaches beyond North America and Europe. Duties will include teaching in the Program in the History of Science and Medicine (Department of History) and in the History of Medicine at the School of Medicine. The search committee will begin considering applications on September 30, 2013. Yale University is an equal opportunity/affirmative action employer and actively encourages applications from minority and women scholars. Ph.D. preferred by the time of appointment. Applicants should send a curriculum vitae, graduate transcript, three letters of recommendation, a statement about their work and professional plans, and a sample of their scholarly writing such as a dissertation or book chapter or article to John Harley Warner, Chair, History of Medicine Search Committee, c/o Ramona Moore, Section of the History of Medicine, Yale University School of Medicine, P.O. Box 208015, New Haven, CT 06520-8015, USA. 


\section{THE BRITISH SOCIETY FOR THE HISTORY OF SGIENGE}

Membership of the Society, which includes a subscription to The British fournal for the History of Science, is open to all persons approved by the Council of the Society and elected at an Extraordinary General Meeting. Details of the annual subscription can be found on our website www.bshs.org.uk or from the Executive Secretary at the address below. There is an Introductory offer for the first year.

The British Journal for the History of Science is the official organ of the Society. All correspondence on the contents of the Journal should be addressed to the Editor, Jon Agar, Department of Science and Technology Studies, University College London, London WC1E 6BT, email ucrhjea@ucl.ac.uk

Book reviews: Books for review should be sent to the Reviews Editor, Dr Adam Mosley, School of Arts and Humanities: History and Classics, Swansea University, Singleton Park, Swansea, SA2 8PP, Wales, United Kingdom.

BSHS publications: BSHS Monograph Series is designed to allow the publication of monographic studies in the history of science quickly and cheaply. Monographs 1-13 are available in digital form and can be downloaded for free via the BSHS website. Monographs 12-14 are available via a print-on-demand service.

Recent titles are as follows:

Images of the Earth: Essays in the History of the Environmental Sciences. Edited by L. J. Jordanova and R. Porter. Second edition. 1997. f17.

Science in Art: Works in the National Gallery that illustrate the History of Science and Technology. By J. V. Field and F. A. J. L. James. 1997. £15.

To See the Fellows Fight: Eye-witness accounts of meetings of the Geological Society of London and its Club, 1822-1868. By J. C.Thackray. 2003. £15.

The Society's magazine, Viewpoint, an informal publication, appears three times a year. It is free to members, $\mathcal{E}^{12.00}$ for institutions and UK non-members, 17.00 for overseas non-members from the Executive Secretary.

Administrative business of the Society is handled by Lucy Santos, Executive Secretary, British Society for the History of Science, PO Box 3401, Norwich, NR7 7JF. The Society is registered in England as a Limited Company (No. 562208) and is a Registered Charity (No. 258854). Email office@bshs.org.uk.

Information about the Society is available through the Internet: http://www.bshs.org.uk

Copying: This journal is registered with the Copyright Clearance Center, 222 Rosewood Drive, Danvers, MA 09123. Organizations in the USA who are also registered with the CGC may therefore copy material (beyond the limits permitted by sections 107 and 108 of US copyright law) subject to payment to CCC of the per-copy fee of $\$ 12.00$. This consent does not extend to multiple copying for promotional or commercial purposes. Code 0007-0874/2013 $\$ 12.00$.

ISI Tear Sheet Service, 3501 Market Street, Philadelphia, Pennsylvania 19104, USA, is authorized to supply single copies of separate articles for private use only.

Organizations authorized by the Copyright Licensing Agency may also copy material subject to the usual conditions Articles from the Journal in electronic or microfiche form can be obtained from Cambridge Journals Online (www.journals.cambridge.org), Proquest (www.proquest.com) and NAPC (www.napubco.com).

For all other use, permission should be sought from Cambridge University Press or from its American branch.

Advertising: Contact the Journals Advertising Manager, Cambridge University Press, University Printing House, Shaftesbury Road, Cambridge CB2 8BS.

Back volumes a limited number of back volumes are available from BSHS Executive Secretary, PO Box 3401, Norwich, NR7 7JF, UK. For Volume 24 onwards, apply to Cambridge University Press in printed form.

Information on the British Fournal for the History of Science and all other Cambridge journals can be accessed via www.journals.cambridge.org

Claims for missing issues should be made immediately on receipt of the subsequent issue.

This journal issue has been printed on FSC-certified paper and cover board. FSC is an independent, non-governmental, not-for-profit organization established to promote the responsible management of the world's forests. Please see www.fsc.org for information.

\section{Printed in the United Kingdom by Bell \& Bain}




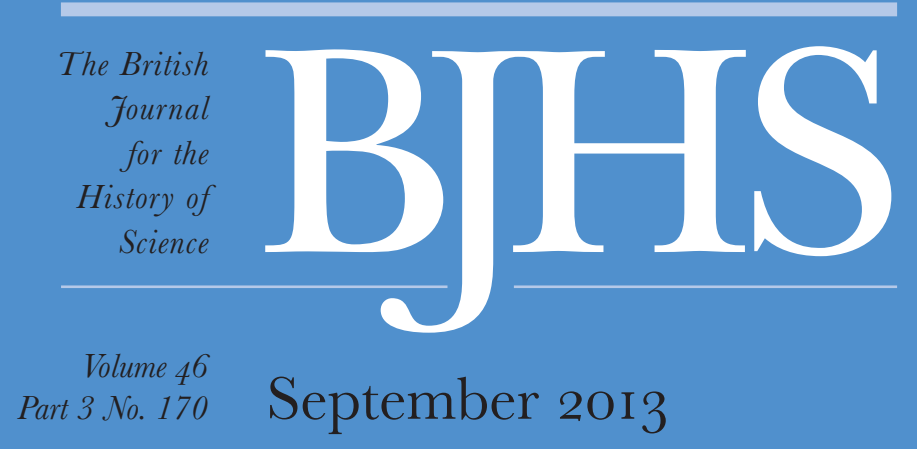

359 Systems of display: the making of anatomical knowledge in Enlightenment Britain CARIN BERKOWITZ

389 'Stargazers at the world's end': telescopes, observatories and 'views' of empire in the nineteenth-century British Empire JOHN MCALEER

415 A Yahgan for the killing: murder, memory and Charles Darwin JOSEPH L. YANNIELLI

445 The politics of participation: Francis Galton's Anthropometric Laboratory and the making of civic selves FRANS LUNDGREN

467 E.B. Tylor, religion and anthropology TIMOTHY LARSEN

487 Anthropology, standardization and measurement: Rudolf Martin and anthropometric photography AMOS MORRIS-REICH

517 Book reviews

547 Books received

\section{B S H S \\ THE BRITISH \\ SOCIETY FOR \\ THE HISTORY \\ OF SCIENCE}

Published for The British Society for the History of Science

by Cambridge University Press 